\title{
Microbial community types and signature-like soil bacterial patterns from fortified prehistoric hills of Thuringia (Germany)
}

\author{
J. Michael Köhler ${ }^{1} \cdot$ Nancy Beetz ${ }^{1} \cdot$ P. Mike Günther ${ }^{1} \cdot$ Frances Möller $^{1} \cdot$ Tim Schüler $^{2} \cdot$ Jialan Cao $^{1}$
}

Received: 18 October 2019 / Accepted: 3 June 2020 / Published online: 17 June 2020

(c) The Author(s) 2020

\begin{abstract}
16S rRNA profiling has been applied for the investigation of bacterial communities of surface soil samples from forestcovered areas of ten prehistorical ramparts from different parts of Thuringia. Besides the majority bacterial types that are present in all samples, there could be identified bacteria that are highly abundant in some places and absent or low abundant in others. These differences are mainly related to the acidity of substrate and distinguish the communities of lime stone hills from soils of sand/quartzite and basalt hills. Minority components of bacterial communities show partially large differences that cannot be explained by the $\mathrm{pH}$ of the soil or incidental effects, only. They reflect certain relations between the communities of different places and could be regarded as a kind of signature-like patterns. Such relations had also been found in a comparison of the data from ramparts with formerly studied $16 S r R N A$ profiling from an iron-age burial field. The observations are supporting the idea that a part of the components of bacterial communities from soil samples reflect their ecological history and can be understood as the "ecological memory" of a place. Probably such memory effects can date back to prehistoric times and might assist in future interpretations of archaeological findings on the prehistoric use of a place, on the one hand. On the other hand, the genetic profiling of soils of prehistoric places contributes to the evaluation of anthropogenic effects on the development of local soil bacterial diversity.
\end{abstract}

Keywords Soil $\cdot$ Bacteria $\cdot$ Diversity $\cdot 16 \mathrm{~S}$ rRNA $\cdot$ Genetic profiling $\cdot$ Ecology $\cdot$ Ramparts $\cdot$ Archaeology

$\begin{array}{ll}\text { Abbreviations } \\ \text { DNA } & \text { Deoxyribonucleic acid } \\ \text { OTU } & \text { Operational taxonomic unit } \\ \text { PCA } & \text { Principal component analysis } \\ \text { PCR } & \text { Polymer chain reaction } \\ \text { ppm } & \text { Parts per million } \\ \text { rRNA } & \text { Ribosomal ribonucleic acid }\end{array}$

Electronic supplementary material The online version of this article (https://doi.org/10.1007/s42974-020-00017-4) contains supplementary material, which is available to authorized users.

J. Michael Köhler

michael.koehler@tu-ilmenau.de

1 Department for Physical, Chemistry and Microreaction Technology, Institute for Micro- and Nanotechnologies/ Institute for Chemistry and Biotechnology, Technische Universität Ilmenau, PF 1005 65, 98684 Ilmenau, Germany

2 Thuringian State Office for Archeology and Monument Conservation, Weimar, Germany

\section{Introduction}

The composition of soil microbial communities is of crucial importance for all terrestrial habitats (Fierer and Jackson 2006). The high diversity of natural soils is mainly determined by the micro-organisms in their interactions with plants, animals, the mineral substrate, chemical ions and compounds dissolved in the soil water and dependent on physical conditions (Fierer and Lennon 2011). The variability of microbial communities is due to the qualitative and quantitative combination of microbial phyla, classes, orders, families, genera and species. The high number of different microbial species and strains generates the potential of a practically infinite size of combinatorial possibilities.

Besides the actual conditions of a place, its preceding development is important for the state of microbial communities, too. The appearance, growth and appearing of macro-organisms, changing weather and climate conditions as well as the varying availability of water and nutrients and the occasional impact of damaging substances affect the development of the different microbes in soil communities. 
These processes are modulating the different kinetics of the different interacting microbial strains (Aanderud et al. 2015).

Besides natural processes, the human impact contributes to the dynamics of the development of soil microbial communities, too. It is obvious that intensive use of surface by agriculture, the construction of industrial facilities and settlements as well as the release of industrial and urban waste have a strong impact on the microbial populations and vice versa, and microbial activities interfere with human impact on environment (Wu et al. 2015). Duration and intensity of human impacts affect the kinetics of microbial growth and the timescales for relaxation and adaptation of communities, too. Therefore, the composition of soil microbial communities reflects not only a recent ecological state of a place, but also its ecological history (Wegner and Liesack 2017). A strong effect is always observed in industrial mining areas, for example, and has also to be reconsidered for the temporal requirements for remediation of damaged areas (Haferburg and Kothe 2010).

Recent investigations argue for the fact that not only the environmental pollution and industrial damages during the last decades are reflected by the biological state of soil, but also earlier human impact is important for recent compositions of soil microbial communities. Also, there are indications for long-term effects of human activities on soil micro-organisms. They can be caused already by preindustrial changes in soil structure and contamination as well as by earlier influences on the distribution of microbial types and on the kinetics of developing microbial communities. Such early effects on recent microbial components in soils can be interpreted by a "soil microbial memory". Examples date back to local situations in the iron age (Margesin et al. 2017).

The investigation of microbial ancient DNA from human remains (Philips et al. 2017) was motivated by the recognition of pathogens (Rollo and Marota 1999; Moodley et al. 2009), on the one hand. On the other hand, profiling of soil microbial DNA was used for characterization of archaeological objects (Lenehan et al. 2017) and evaluation of degradation and preservation conditions (McNamara et al. 2005; Douterelo et al. 2010; Xu et al. 2017). The investigation of archaeological material by r-RNA profiling showed significant differences between the bacterial communities of excavated objects and the surrounding soil on lower taxonomical levels, but larger similarities on the phylum level (Kazarina et al. 2019). The determination of abundances of extremophiles could support specific insights into the interpretation of archaeological findings, for example by the enhanced presence of thermophilic bacteria (Chernysheva et al. 2017).

Here, it tries to distinguish between the influences of general natural conditions and specific local features on soil bacteria communities of some prehistorically used places by comparing data of $16 \mathrm{~S} r R N A$ profiling. Prehistorically fortified hills of Thuringia (Germany) in different geological situations have been chosen as an example for this investigation. In the following, the sequence data of soil samples from selected places will be discussed and the results are interpreted in comparison with each other and with recently obtained data from an archaeological excavation on an ironage burial place (Köhler et al. 2018).

\section{Experiments}

\section{Soil samples and sampling places}

The soil samples were taken from open spots of the forest soil of areas of prehistoric ramparts. The majority of them are regarded to be fortified hill settlements. These settlements have been deserted in prehistoric times. In case of the hill of Hasenburg, the place was later used for constructing a mediaeval castle, which was deserted, too, about 800 years ago. The state of archaeological investigation of the ramparts is different. Detailed studies are reported from the multiphase hill settlement and Celtic oppidum Steinsburg near Römhild (Peschel 2005), from the pre-Roman iron-age settlements on Öchsen near Vacha (Donat 1966). Dating artefacts have also been found on Diesburg near Aschenhausen (Peschel 2004), Röderburg (near Dermbach), on Herrenberg near Theuern (Gall 1994) and from the late bronze/ early iron-age rampart of Ole Burg near Sondershausen. The fortified multiphase hill settlements of Monraburg near Beichlingen (Simon 1984) and Hasenburg near Haynrode (Peschel 1986) are archaeologically studied, whereas the ramparts of Aaskehren (near Bleicherode) and the rectangular wall in the Lange Bahn forest (not identical with the deserted mediaeval settlement "Lange Bahn") near Suhl have not been archaeologically investigated in detail, up to now. The sample material was taken from vegetation-free spots on the surface. The sample material was filled into sterile $50-\mathrm{mL}$-sample tubes and stored and transported by them in the laboratory. The samples have been dried and stored at room temperature. The sampling locations (Fig. 1) are identified by GPS. The sample origin and locations are described in detail in Table 1.

\section{DNA extraction, amplification, labelling and data processing}

The DNA of soil samples was extracted by a Power Soil Isolation Kit (MO BIO, Carlsbad, USA) according to the manufacturer's protocol and processed as published (Köhler et al. 2018). An Edvocycler (Edvotek, Washington D.C.) was applied for DNA amplification by polymer chain reaction (PCR). Each PCR amplification step was verified by gel electrophoresis. Therefore, $1.2 \%$ agarose gels were applied. 
Fig. 1 Sampling locations in Thuringia/Germany

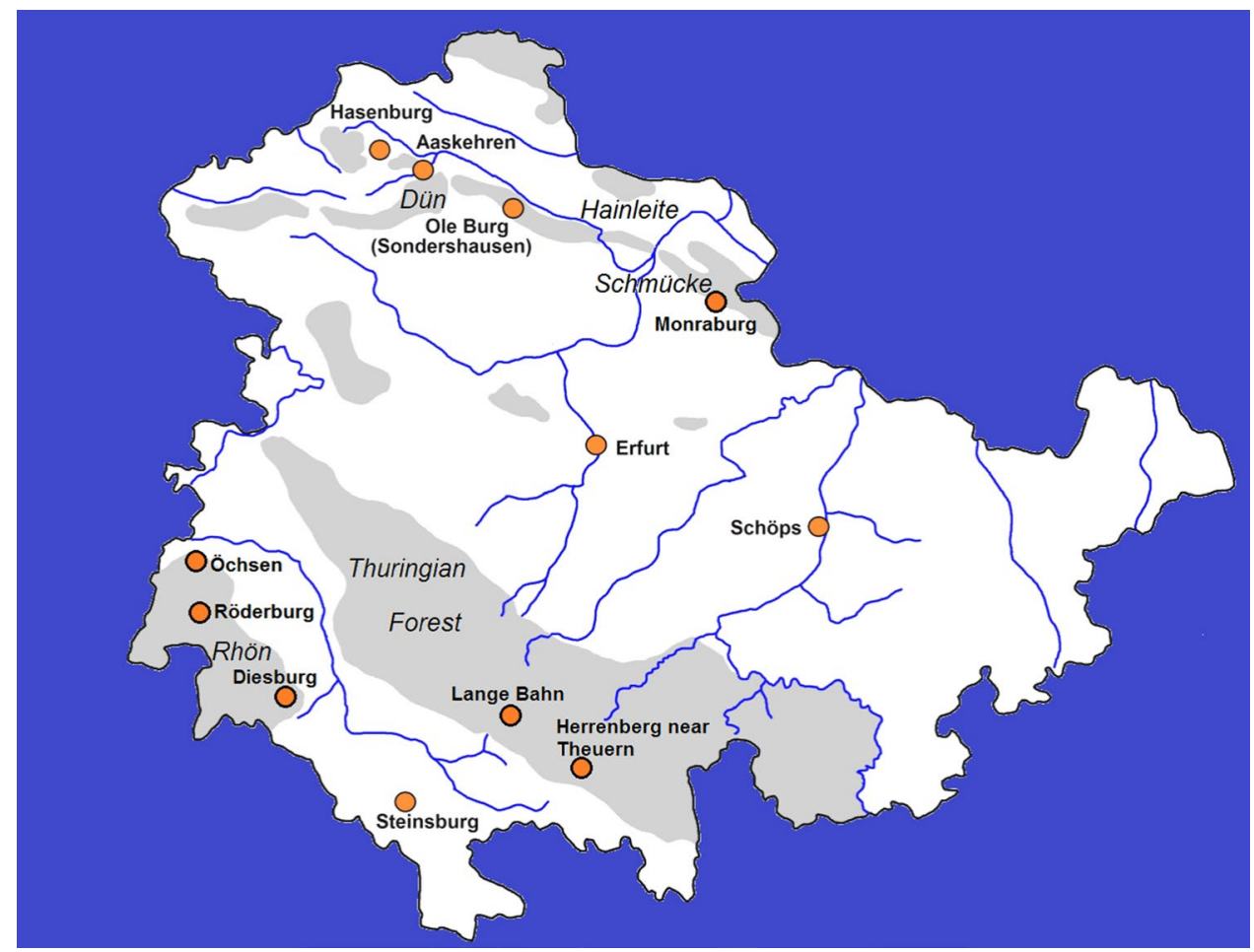

Single PCR products, as well as pooled DNA libraries, were purified with AMPure XP beads (Beckman Coulter, Brea, USA).

For amplicon PCR, adaptor primers A519F-Ad (5' TCG TCGGCAGCGTCAGATGTGTATAAGAGACAGCAG CMGCCGCGGTAA 3') and Bact_805R-Ad (5'-GTCTCG TGGGCTCGGAGATGTGTATAAGAGACAGGACTACHVGGGTATCTAATCC 3 ') were used (100 pmol/ $\mu \mathrm{L})$, which were obtained from Eurofins Genomics (Ebersberg, Germany). The reaction mixtures with a total volume of $50 \mu \mathrm{l}$ per reaction contained $1 \mu \mathrm{L}$ of DNA isolation eluate, $2 \mathrm{mM}$ $\mathrm{MgCl}_{2}, 200 \mu \mathrm{M}$ PCR nucleotide mix, 1,25 Units GoTaq G2 Flexi DNA Polymerase, nuclease-free water (all reagents from Promega, Madison (USA)) and $1 \mu \mathrm{mol} / \mathrm{l}$ of each primer. Amplicon PCR programme settings were as follows: $94{ }^{\circ} \mathrm{C}$ for $5 \mathrm{~min}, 30$ cycles of denaturation at $94{ }^{\circ} \mathrm{C}$ for $30 \mathrm{~s}$; annealing at $50{ }^{\circ} \mathrm{C}$ for $30 \mathrm{~s}$; extension at $72{ }^{\circ} \mathrm{C}$ for $30 \mathrm{~s}$; and a final extension at $72{ }^{\circ} \mathrm{C}$ for $5 \mathrm{~min}$.

The quality of the sequence data was checked by a sample of 16 of the data sets using the tool "Galaxy" (http://hanno nlab.cshl.edu/fastx_toolkit/; A. Gordon 2010). All checked data sets show a high median quality score (examples in Supplementary 2). An average of 37.4 was found in the median quality scores (based on a scale from -15 to 40 ). In total, $94.1 \%$ of the median quality scores are above 35 . Only, a very low decay in the score values was observed (Graph in Supplementary 2).

The automatic software pipeline of the SILVAngs data analysis service (https://ngs.arb-silva.de/silvangs; Quast et al.
2013, Yilmaz et al. 2014, Klindworth et al. 2013) was used for the community analysis of the NGS data. All data files from GATC Biotech first had to be converted from fastq file format to fasta file format, because the fastq file format was not compatible to upload. The used fastq-to-fasta converter software was "phred33 conversion" from MR DNA Lab. All data sets were analysed using the preset parameters of the settings page and with the SILVAngs database release version 128 (Yilmaz et al. 2014).

Only a part of the assigned bacterial groups could be assigned down to the genus level. Other groups can only be identified with higher taxonomical levels as family, order, class or phylum. The lowest identified level was always referenced as "operational taxonomic unit" (OTU).

For similarity analyses, the absolute number of reads per place or per sample had been used, on the one hand. The absolute number $\mathrm{n}$ has mainly been applied for comparing samples by less abundant OTUs and by a search for rare patterns in the presence of soil bacteria. On the other hand, normalized frequency data had been calculated for the comparison of samples by higher abundant OTUs. Therefore, a relative abundance value $r$ and a Shannon diversity-related $h$ value were calculated for each OTU in each sample from the individual number of reads $\mathrm{n}$, the total number of reads of each sample $\mathrm{N}$ and the total of $r$ values from all samples $R$ of each OTU.

$r_{i j}=\log \left[10^{6} *\left(1+n_{i j}\right) / N_{j}\right]$ 
Table 1 Origin of samples

\begin{tabular}{|c|c|c|c|c|}
\hline \multirow[t]{2}{*}{ Location } & \multirow[t]{2}{*}{ Sample no. } & $\begin{array}{l}\text { Internal } \\
\text { Laboratory sample }\end{array}$ & \multicolumn{2}{|c|}{$\begin{array}{l}\text { Gauss-Krüger coordi- } \\
\text { nates }\end{array}$} \\
\hline & & No. & $\mathrm{r}$ & $\mathrm{h}$ \\
\hline Römild, Steinsburg & $1 \mathrm{a}$ & B11 & 4399747 & 5586335 \\
\hline Römild, Steinsburg & $1 b$ & B12 & 4399713 & 5587157 \\
\hline Römild, Steinsburg & $1 \mathrm{c}$ & B13 & 4399713 & 5587164 \\
\hline Römild, Steinsburg & $1 d$ & B14 & 4399727 & 5587362 \\
\hline Römild, Steinsburg & $1 \mathrm{e}$ & B15 & 4400109 & 5587413 \\
\hline Römild, Steinsburg & 1f & B16 & 4400094 & 5587204 \\
\hline Römild, Steinsburg & $1 \mathrm{~g}$ & B17 & 4400238 & 5586986 \\
\hline Römild, Steinsburg & $1 \mathrm{~h}$ & B18 & 4400116 & 5586747 \\
\hline Aschenhausen, Diesburg & $2 \mathrm{a}$ & $\mathrm{T} 15-1$ & 3586124 & 5606568 \\
\hline Aschenhausen, Diesburg & $2 b$ & T16-1 & 3586099 & 5606493 \\
\hline Aschenhausen, Diesburg & $2 \mathrm{c}$ & $\mathrm{T} 17-1$ & 3586023 & 5606384 \\
\hline Aschenhausen, Diesburg & $2 \mathrm{~d}$ & $\mathrm{~T} 18-1$ & 3586091 & 5606482 \\
\hline Aschenhausen, Diesburg & $2 \mathrm{e}$ & T19-1 & 3586129 & 5606346 \\
\hline Vacha, Öchsen & $3 a$ & T61-1 & 3572501 & 5630023 \\
\hline Vacha, Öchsen & $3 b$ & T61-2 & 3572501 & 5630023 \\
\hline Vacha, Öchsen & $3 \mathrm{c}$ & T62-1 & 357252 & 5630013 \\
\hline Vacha, Öchsen & $3 d$ & T62-2 & 357252 & 5630013 \\
\hline Vacha, Öchsen & $3 e$ & T63-1 & 3572523 & 563001 \\
\hline Vacha, Öchsen & $3 f$ & T63-2 & 3572523 & 563001 \\
\hline Vacha, Öchsen & $3 g$ & T64 & 3572854 & 5629539 \\
\hline Dermbach, Röderburg & $4 \mathrm{a}$ & $\mathrm{T} 31$ & 3576057 & 5620666 \\
\hline Dermbach, Röderburg & $4 \mathrm{~b}$ & $\mathrm{~T} 32$ & 3575996 & 5620664 \\
\hline Dermbach, Röderburg & $4 \mathrm{c}$ & $\mathrm{T} 33$ & 357602 & 5620561 \\
\hline Dermbach, Röderburg & $4 d$ & T35 & 3576082 & 5620474 \\
\hline Haynrode, Hasenburg & $5 \mathrm{a}$ & B1 & 3603574 & 5702945 \\
\hline Haynrode, Hasenburg & $5 b$ & B2 & 3603355 & 5702923 \\
\hline Haynrode, Hasenburg & $5 \mathrm{c}$ & B3 & 3603337 & 5702946 \\
\hline Haynrode, Hasenburg & $5 \mathrm{~d}$ & B4 & 3603431 & 5702634 \\
\hline Haynrode, Hasenburg & $5 \mathrm{e}$ & V1 & 3603342 & 5702981 \\
\hline Haynrode, Hasenburg & $5 f$ & V2-1 & 3603331 & 5702839 \\
\hline Haynrode, Hasenburg & $5 \mathrm{~g}$ & V2-2 & 3603331 & 5702839 \\
\hline Haynrode, Hasenburg & $5 \mathrm{~h}$ & V3-1 & 3603331 & 570282 \\
\hline Haynrode, Hasenburg & $5 \mathrm{i}$ & V3-2 & 3603331 & 570282 \\
\hline Haynrode, Hasenburg & $5 \mathrm{j}$ & V4-1 & 360336 & 360336 \\
\hline Haynrode, Hasenburg & $5 \mathrm{k}$ & V4-2 & 360336 & 360336 \\
\hline Haynrode, Hasenburg & 51 & V5 & 3603354 & 5702754 \\
\hline Beichlingen, Monraburg & $6 \mathrm{a}$ & $\mathrm{T} 72$ & 4450469 & 5678312 \\
\hline Beichlingen, Monraburg & $6 \mathrm{~b}$ & $\mathrm{~T} 73$ & 4450782 & 5678244 \\
\hline Beichlingen, Monraburg & $6 \mathrm{c}$ & $\mathrm{T} 74$ & 4450792 & 5678243 \\
\hline Beichlingen, Monraburg & $6 \mathrm{~d}$ & $\mathrm{~T} 75$ & 4450676 & 5678237 \\
\hline Beichlingen, Monraburg & $6 e$ & T76 & 4450687 & 5678271 \\
\hline Beichlingen, Monraburg & $6 f$ & $\mathrm{~T} 77$ & 445071 & 5678328 \\
\hline Beichlingen, Monraburg & $6 \mathrm{~g}$ & $\mathrm{~T} 78$ & 4450687 & 5678354 \\
\hline Beichlingen, Monraburg & $6 \mathrm{~h}$ & T79 & 4450577 & 5678428 \\
\hline Sondershausen, Ole Burg & $7 \mathrm{a}$ & B43-1 & 4418982 & 5690304 \\
\hline Sondershausen, Ole Burg & $7 \mathrm{~b}$ & B45-1 & 4418897 & 5690399 \\
\hline Sondershausen, Ole Burg & $7 \mathrm{c}$ & B46-1 & 4418862 & 5690465 \\
\hline
\end{tabular}


Table 1 (continued)

\begin{tabular}{|c|c|c|c|c|}
\hline \multirow[t]{3}{*}{ Location } & \multirow[t]{3}{*}{ Sample no. } & \multirow{2}{*}{$\begin{array}{l}\text { Internal } \\
\text { Laboratory sample }\end{array}$} & \multicolumn{2}{|c|}{$\begin{array}{l}\text { Gauss-Krüger coordi- } \\
\text { nates }\end{array}$} \\
\hline & & & & \\
\hline & & No. & $\mathrm{r}$ & $\mathrm{h}$ \\
\hline Bleicherode, Aaskehren & $8 \mathrm{a}$ & $\mathrm{T} 1-1$ & 4400216 & 5700617 \\
\hline Bleicherode, Aaskehren & $8 b$ & $\mathrm{~T} 2-1$ & 4400548 & 5700676 \\
\hline Bleicherode, Aaskehren & $8 \mathrm{c}$ & T3-1 & 4400731 & 570053 \\
\hline Bleicherode, Aaskehren & $8 \mathrm{~d}$ & $\mathrm{~T} 4-1$ & 4400691 & 5700481 \\
\hline Theuern, Herrenberg & $9 \mathrm{a}$ & T40-1 & 4430138 & 5589078 \\
\hline Theuern, Herrenberg & $9 b$ & $\mathrm{~T}-40-2$ & 4430138 & 5589078 \\
\hline Theuern, Herrenberg & $9 \mathrm{c}$ & $\mathrm{T} 41-1$ & 4430187 & 5589051 \\
\hline Theuern, Herrenberg & $9 \mathrm{~d}$ & $\mathrm{~T} 41-2$ & 4430187 & 5589051 \\
\hline Theuern, Herrenberg & $9 \mathrm{e}$ & $\mathrm{T} 42-1$ & 4430152 & 5589113 \\
\hline Theuern, Herrenberg & 9f & $\mathrm{T} 42-2$ & 4430152 & 5589113 \\
\hline Suhl, Forest Lange Bahn & $10 \mathrm{a}$ & $\mathrm{T} 51$ & 4403701 & 5605545 \\
\hline Suhl, Forest Lange Bahn & $10 \mathrm{~b}$ & $\mathrm{~T} 52$ & 4403665 & 5605577 \\
\hline Suhl, Forest Lange Bahn & $10 \mathrm{c}$ & $\mathrm{T} 53$ & 4403641 & 5605553 \\
\hline Suhl, Forest Lange Bahn & $10 \mathrm{~d}$ & $\mathrm{~T} 54$ & 4403608 & 5605573 \\
\hline Suhl, Forest Lange Bahn & $10 \mathrm{e}$ & T55 & 4403607 & 5605573 \\
\hline Schöps ${ }^{*}$ & HB11 & urn & 4471485 & 5633000 \\
\hline Schöps & HB12 & reference & 4471485 & 5633000 \\
\hline Schöps & HB13 & urn & 4471479 & 5633028 \\
\hline Schöps & HB14 & reference & 4471479 & 5633028 \\
\hline Schöps & HB15 & urn & 4471498 & 5633016 \\
\hline Schöps & HB16 & reference & 4471498 & 5633016 \\
\hline Schöps & HB17 & urn & 4471495 & 5633084 \\
\hline Schöps & HB18 & reference & 4471495 & 5633084 \\
\hline Schöps & HB19 & urn & 4471499 & 5633071 \\
\hline Schöps & HB20 & reference & 4471499 & 5633071 \\
\hline
\end{tabular}

*The results on the investigations of the samples from Schöps are reported (Köhler et al. 2018): "urn" means a sample, which was taken from the soil material inside a urn, and "reference" means sample material, which was taken from the soil of the same spot, but outside the same urn

$h_{i j}=(-1) * r_{i j} / R_{j} * \ln \left(r_{i j} / R_{j}\right)$

The value $\mathrm{r}$ can be regarded as the $\log (\mathrm{ppm})$ value for the relative number of reads per sample + one. The "ppm" value means "part per million". The value h represents the contribution of each sample to the total Shannon diversity of the whole sample set. The total of these values $h$ result in the Shannon diversity index $\mathrm{H}$ for each OTU in the investigated set of 72 samples with a $H_{\max }$ value of $4.2767[=\ln (72)]$. This parameter is high if a micro-organism component is present in many samples in a similar concentration. It is low in case of the dominance of an OTU in a few samples, only.

\section{Results and discussion}

\section{Community types of different types of sampling locations}

The soil bacterial communities from the different sampling sites have been characterized by their taxonomic profiles. Proteobacteria, Bacteriodetes, Actinobacteria and Acidobacteria are the most abundant phyla (Fig. 2). Larger differences have been observed in the abundancies 


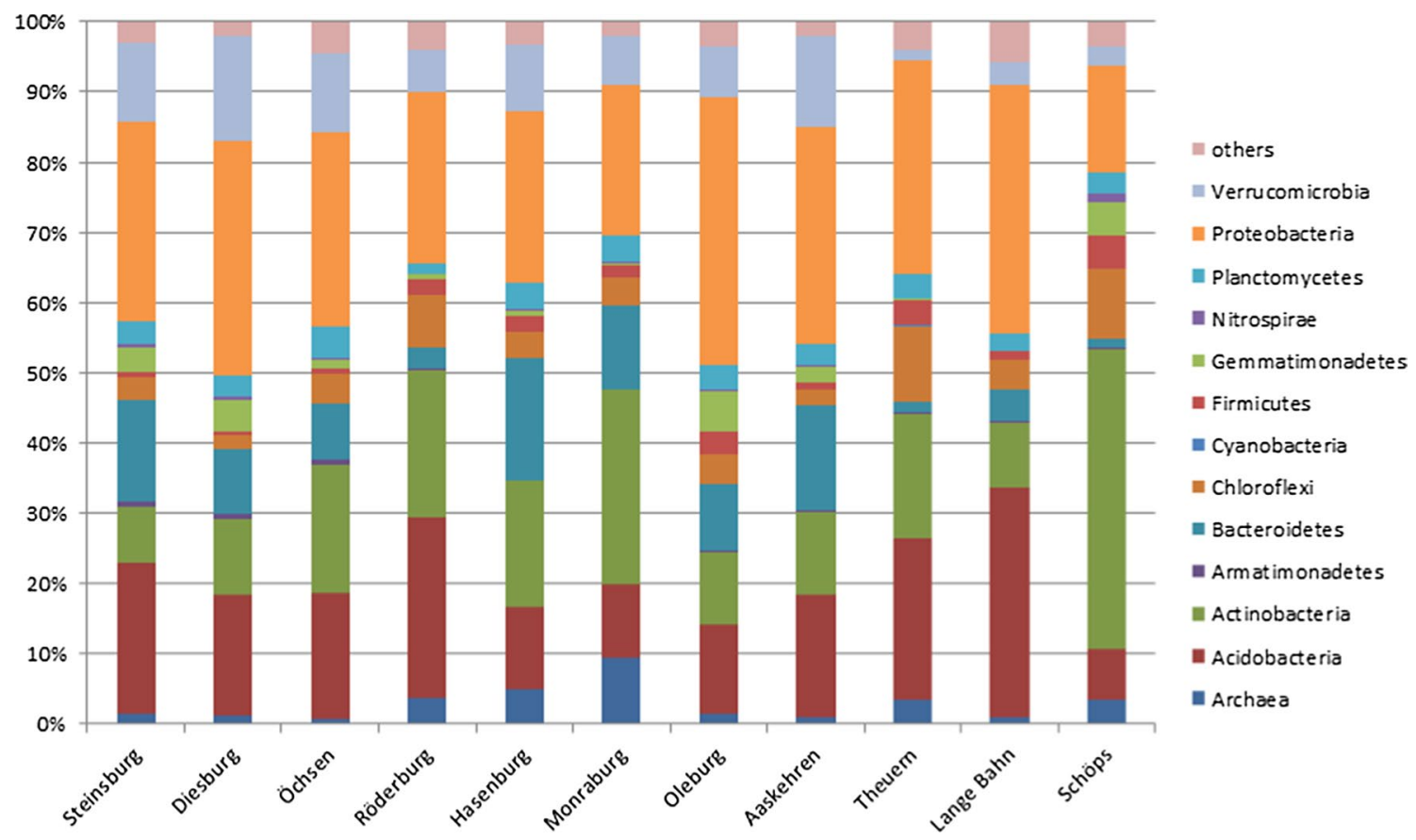

Fig. 2 Taxonomic profile (phylum level) of the investigated sampling places

of Verrucomicrobia, Nitrospirae, Gemmatimonadetes, Firmicutes and Archaea.

The more abundant OTUs can be distinguished by their diversity over the whole sample set. Figure 3 shows examples of correlations of pairs of arbitrarily selected OTUs from different ranges of $H / H_{\text {max }}$ values (normalized Shannon diversity index). The upper part (Fig. 3a) shows the distribution of r values of Acidimicrobiia IMCC26256 and Pirellulaceae, uncult., which are marked by a narrow diversity corresponding to high $H / H_{\max }$ values of 0.96 . They belong to a group of OTUs which are highly abundant in all places. The middle and the lower parts (Fig. 3b, c) show that the OTUs Ilimobacteraceae, uncult. and Chloroflexi TK10 $\left(H / H_{\max }=0.9\right)$ have a higher distribution, and Gemmatimonas and Acidobacteria, Subgroup $22\left(H / H_{\max }=0.76\right)$ have a very high distribution of abundance in the whole set of investigated samples. Figure 3 illustrates the fact that groups of OTUs with different frequency distribution can be distinguished by their $H$ values.

It was expected that the bacterial soil communities differ in dependence on the geological ground and the soil substrate. Therefore, it was investigated whether the groups of the different regions of Thuringia of different geological situations can be distinguished. A group of OTUs (supplementary Table 1) with higher abundance and moderate normalized diversity index $H / H_{\max }$ of ppm values has been chosen for a principal component analysis (PCA). OTUs with moderate values of $H / H_{\max }$ have been chosen to have a good representation of OTUs with high differences in their abundancies, on the one hand, and to avoid an over-representation of OTUs which are only present in a few samples, on the other hand. Comparable high values (near one) result from the logarithmic definition of $\mathrm{r}$ (Eq. 1). The application of the logarithmic values corresponds to the fact that the abundance of OTUs differs by orders of magnitudes. The application of logarithmic values helps to avoid an over-representation of very frequent OTUs and an under-estimation of OTUs with mediate abundance. The PC1/PC2 plot indicates the similarity of samples within each region and differences between the regions related to the selected OTUs (Fig. 4). The samples of the excavation of the burial place (Schöps, circles), the samples of all four Northern Thuringian hills (squares) and the samples from the investigated places of Thuringian Forest (triangles) are clustered and well separated from each other in the plane of the principal components 1 and 2 (Fig. 4a). A broader distribution was only observed in the case of the basalt hill samples (open diamonds). But the samples of this group can also mostly be distinguished from the quartz and sand-based soils (acidic mineral substrate) of the Thuringian Forest places by regarding the $\mathrm{PC} 1 / \mathrm{PC} 3$ plot (third principal component, Fig. 4b). The samples of Hasenburg and Monraburg are particularly highly related. This is probably mainly caused by the similarities in soil substrate and vegetation, but it had also to be reconsidered that both places have important analogies in their ancient fate. Both places are multiphase hill settlements with artefacts from Neolithic 

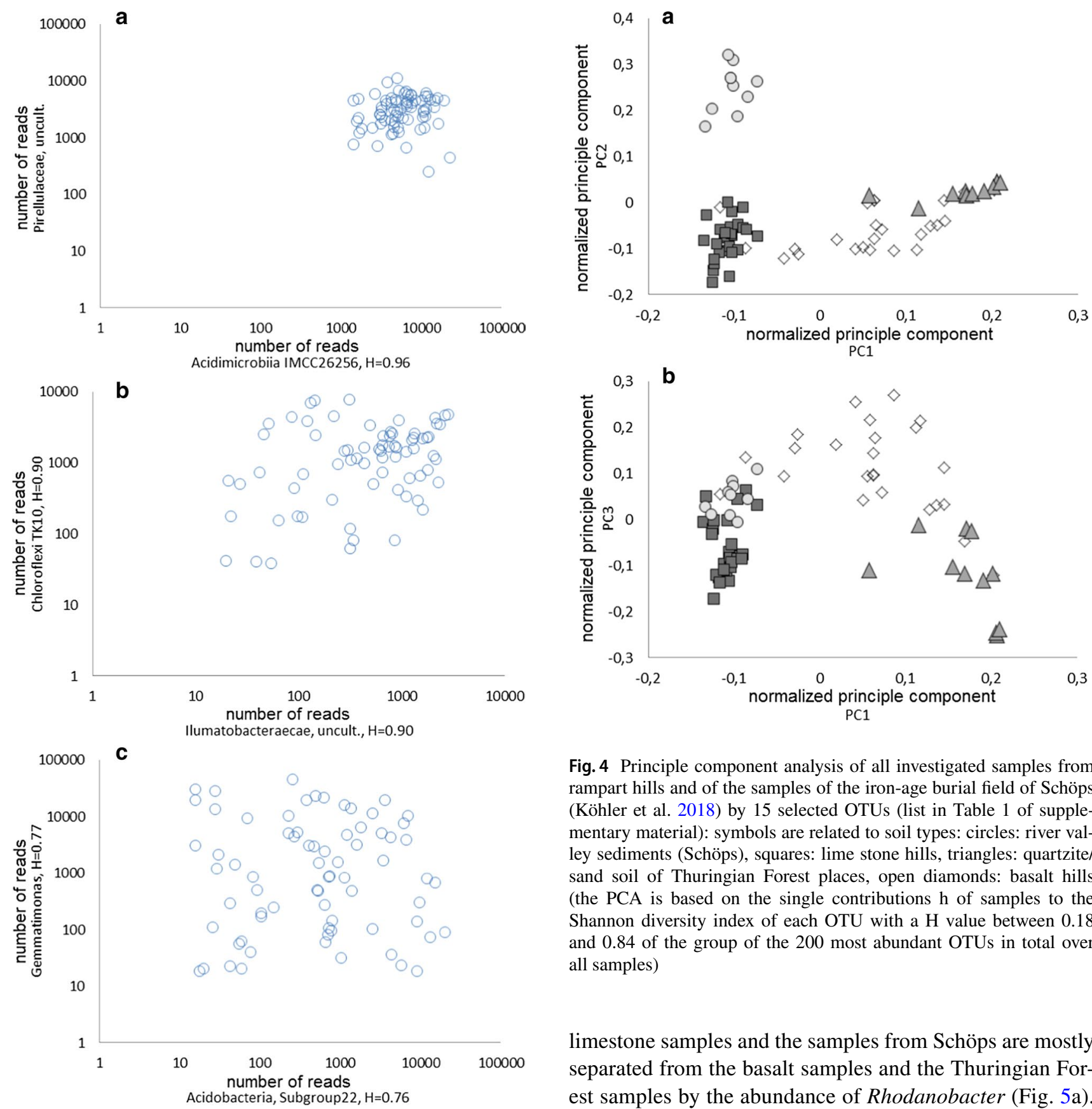

Fig. 4 Principle component analysis of all investigated samples from rampart hills and of the samples of the iron-age burial field of Schöps (Köhler et al. 2018) by 15 selected OTUs (list in Table 1 of supplementary material): symbols are related to soil types: circles: river valley sediments (Schöps), squares: lime stone hills, triangles: quartzite/ sand soil of Thuringian Forest places, open diamonds: basalt hills (the PCA is based on the single contributions $\mathrm{h}$ of samples to the Shannon diversity index of each OTU with a $\mathrm{H}$ value between 0.18 and 0.84 of the group of the 200 most abundant OTUs in total over all samples)

limestone samples and the samples from Schöps are mostly separated from the basalt samples and the Thuringian Forest samples by the abundance of Rhodanobacter (Fig. 5a). Ferruiginibacter was described as an isolate from freshwater

Fig. 3 Correlation of 3 pairs of selected OTUs (higher total abundance) of different Shannon diversity index: a $H / H_{\max }=0.96 ; \mathbf{b}$ $H / H_{\max }=0.90 ; \mathbf{c} H / H_{\max }=0.76$

Age over the late bronze age and the early iron age up to a mediaeval re-settlement and re-fortification (Peschel 1986; Simon 1984).

The clustering of regions is also visible by the abundant distribution of some selected single OTUs. Most samples of lime stone and basalt hills can be distinguished by the excavation samples of Schöps and the hills of Thuringian Forest by the abundance of Ferruginibacter, whereas the sediment (Lim et al. 2009), the genus Rhodanobacter for a strain which is able to mineralize the insecticide Lindane (Nalin et al. 1999). In contrast to the basalt places, the three other sample groups are also well distinguishable by the abundances of Adhaeribacter and the Actinobacter group MB-A2-108 (Fig. 5b). Like Ferruginibacter, Adhaeribacter, too, is related to freshwater and was isolated from a biofilm in a freshwater tank (Rickard et al. 2005). As it is visible, the basalt hill samples differ much more from each other, and some of these samples are closely related to the Thuringian Forest samples concerning the both last mentioned OTUs. The samples of Schöps have a high content of the 

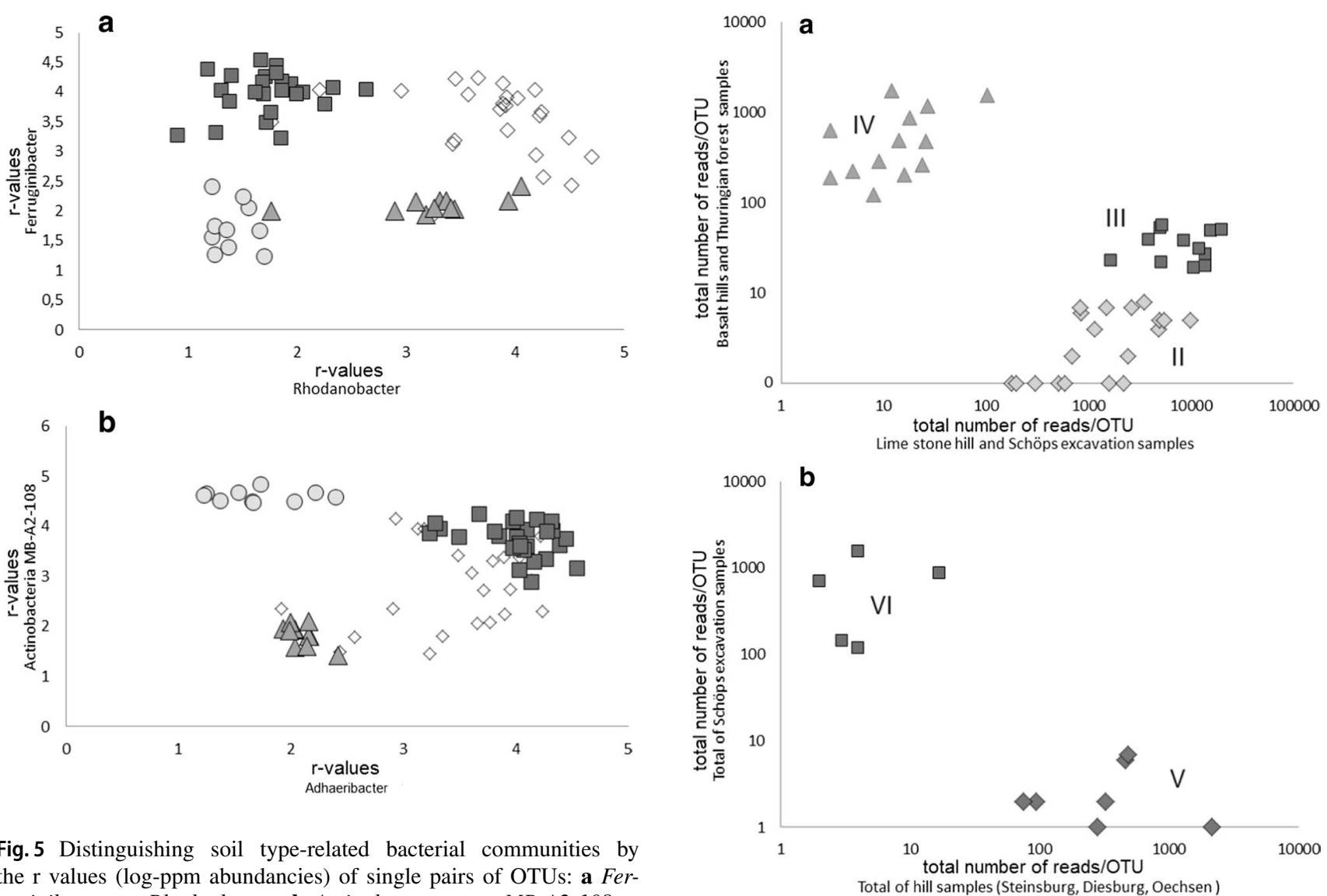

Fig. 5 Distinguishing soil type-related bacterial communities by the $\mathrm{r}$ values (log-ppm abundancies) of single pairs of OTUs: a Ferruginibacter vs Rhodanbacter, b Actinobacter group MB-A2-108 vs Adhaeribacter (symbols are related to soil types: circles: river valley sediments (Schöps), squares: lime stone hills, triangles: quartzite/sand soil of Thuringian Forest places, open diamonds: basalt hills)

Actinobacter MB-A2-108 group, but no or low content of Adhaeribacter, whereas this last mentioned OTU is present in all limestone hill samples. The samples of both investigated Thuringian Forest places show low content of Adhaeribacter as well as of the Actinobacter group (Table 2). It seems to be plausible that the samples from the archaeological excavation (circles in Fig. 5a, b) are related to the low content of the freshwater-related OTUs because the concerned soil was covered by a soil top layer for about 20 centuries.

Besides the distinguishing of all four groups of places with different soil types, it is possible to distinguish sampling places by selected groups of OTUs (listed in supplementary 1). Thus, three groups of OTUs are well reflected by their abundancies on the Basalt hill and Thuringian Forest samples, on the one hand, and the lime stone hill and the Schöps excavation samples, on the other hand (Fig. 6). Two other groups of OTUs distinguish clearly between the Schöps excavation samples and samples of three of the basalt hills. It is remarkable that in this case, the fourth basalt hill place (Röderburg) does not match the other basalt hills. The Röderburg samples are marked

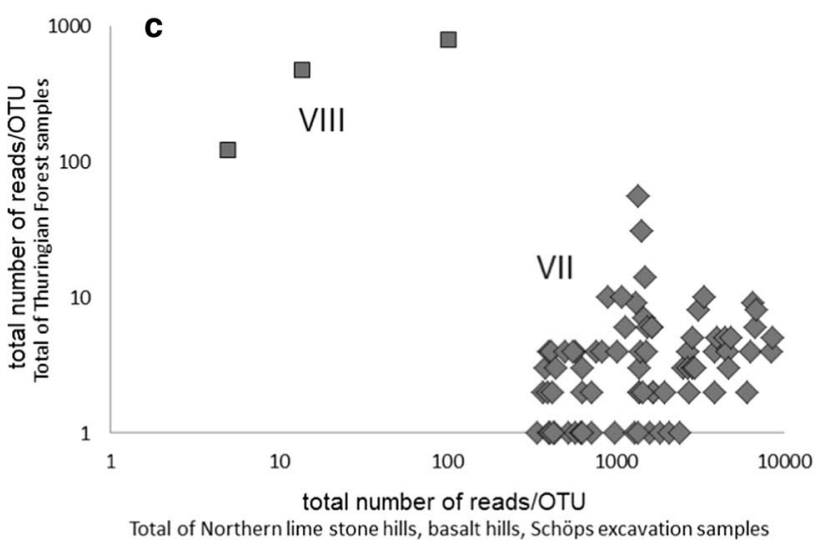

Fig. 6 Distinguishing sample groups by groups of OTUs (total number of reads per OTU for sample groups, Roman numbers characterize groups of OTUs): a Basalt hill and Thuringian Forest samples versus lime stone hill and Schöps samples, b Schöps samples versus three basalt hill samples, $\mathbf{c}$ Thuringian Forest samples versus all other samples

by the absence or very low abundancies of organisms of group IV and group V, which corresponds to the features of the Thuringian Forest samples. These last mentioned places (Theuern and Lange Bahn) are distinguishable from all other types of samples (including the samples of 
Table 2 Distinction of samples from different soil types by four selected OTUs

Adhaeribacter

Actinobacter MB- Ferruginibacter

Rhodanobacter A2-108

\begin{tabular}{|c|c|c|c|c|}
\hline Schöps (river valley sediments) & Low & High & Low & Low \\
\hline Northern Thuringia hill ramparts (lime stone soil) & High & High & High & Low \\
\hline $\begin{array}{l}\text { Thuringian Forest ramparts/settlements (quartzite/sand stone } \\
\text { substrate) }\end{array}$ & Low & Low & Low & High \\
\hline Southwest Thuringian hill settlements (basalt substrate) & Different & Different & High & High \\
\hline
\end{tabular}

Röderburg) by OTUs of two other groups (VII and VIII) as shown in Fig. 6c. The OTU groups II-VIII are listed in Table 2-4 of supplementary material 1 .

\section{Search for soil microbial signatures on rampart places}

Besides bacterial types (OTUs) with higher abundance on several places ("majority components"), there are some "minority components" which are present at one rampart place only, but had not found in the profiling of any other place. The number of these "exclusively" found OTUs differ between the places (supplementary 1, Table 5). The number of reads per OTU is very low in most cases. It might be that some of these OTUs are typical for a place, but a considerable part of these OTUs was probably found accidentally.

Besides these types, there are other small groups of OTUs that are found in two or several samples from the same place. Also in these cases, some OTUs might be found accidentally, but some patterns seem to be characteristic of a group of samples from the same place (supplementary 1, Table 6). Similarities are observed in patterns of places with similar types of soil. This confirms the above-described significant relation between the bacterial communities of different places with the same geological situation. Thus, minority types that have been observed in samples from Steinsburg (basalt substrate) are partially found in other basalt hills, too. In the case of the set of samples from Hasenburg (limestone substrate), an enhanced number of reads of two minority OTUs (Bacteriovoracaceae, uncultured and Rubinisphaeraceae, uncultured) distinguishes these samples from the samples of other places. Even on the other limestone hills, only one of these both OTUs is enhanced in the samples (for data see also supplementary 1, Table 6; Hasenburg). An example of a signature-like pattern with stronger enhanced numbers of reads was detected of one sample of Ole Burg (place No. 7) and Aaskehren (place No. 8). The combined significant presence of a group of four OTUs (Anaerosporomusa, Anaerolinea, Desulfuromonas, Gracilibacter) was observed in these two samples, but in no other samples. It is remarkable that all four OTUs are described to thermophilic, partially, and are related to anaerobic conditions (Sekiguchi et al. 2003; Lee et al. 2006; Choi et al. 2016).

Despite the similarities between samples of the same place and samples with similar soil conditions, there are also small sets of minority OTUs which are found in a few places only. These OTUs or small sets of them can be regarded as connecting certain places (examples in Fig. 7). Thus, a set of four minority OTUs (Desulf. MA-28-I98C, Ignavibacterium, Cand. Vogelbacteria, Vadin HA17) connects the samples of Öchsen (basalt hill, Rhön) with samples of Ole Burg (limestone hill, Northern Thuringia). Another set of seven OTUs (Thermoplasmata, uncult., Ktedenobacterales Bac C-u-018, Dermococcaceae, uncult., Acdiobacillus, Actinocatenispora, Methyloparacoccus, Methanobacterium) connects the basalt hill of Röderburg (Rhön) with the rampart of Theuern in the Thuringian Forest (quartzite, sand soil). Four of these OTUs have been also found on the rampart of Lange Bahn in the Thuringian Forest, two of them on Öchsen. It is remarkable that a group of anaerobic and methanotrophic OTUs (Hoefman et al. 2014) is important for these relations between the places, too. The ramparts of Lange Bahn and Theuern supplied a group of four common OTUs (Acidobacterium, Natroniella, Telmatobacter, Orenia) which are known to be connected with extremeous $\mathrm{pH}$, salt content and anaerobic conditions (Kishimoto et al. 1991; Zhilina et al. 1996; Mouné et al. 2000; Pankratov et al. 2012).

Interesting differences in the bacterial communities have been found between two samples of the interior of the rectangular rampart of Lange Bahn and two reference samples taken a few metres outside of this rampart. Inside the wall area, several OTUs had been found which are very low or not present outside (Table 7 of supplementary material 1). Among them are a conspicuous number of OTUs of Ktedonobacteria, which attract interest due to expectations to producing useful secondary metabolites (S. Yabe et al. 2017). Further, several OTUs of the family Beijerinckiaceae have been found inside the wall area, among them Methylocapsa and Methylocella two acidiophilic and methanotrophic bacteria (SN Dedysh et al. 2002, SN Dedysh et al. 2005). With Streptacidiphilus (S.B. Kim et al. 2003), Catenulispora (E. Busti et al. 2006) and Actinospica (L. Cavaletti et al. 2006) further 


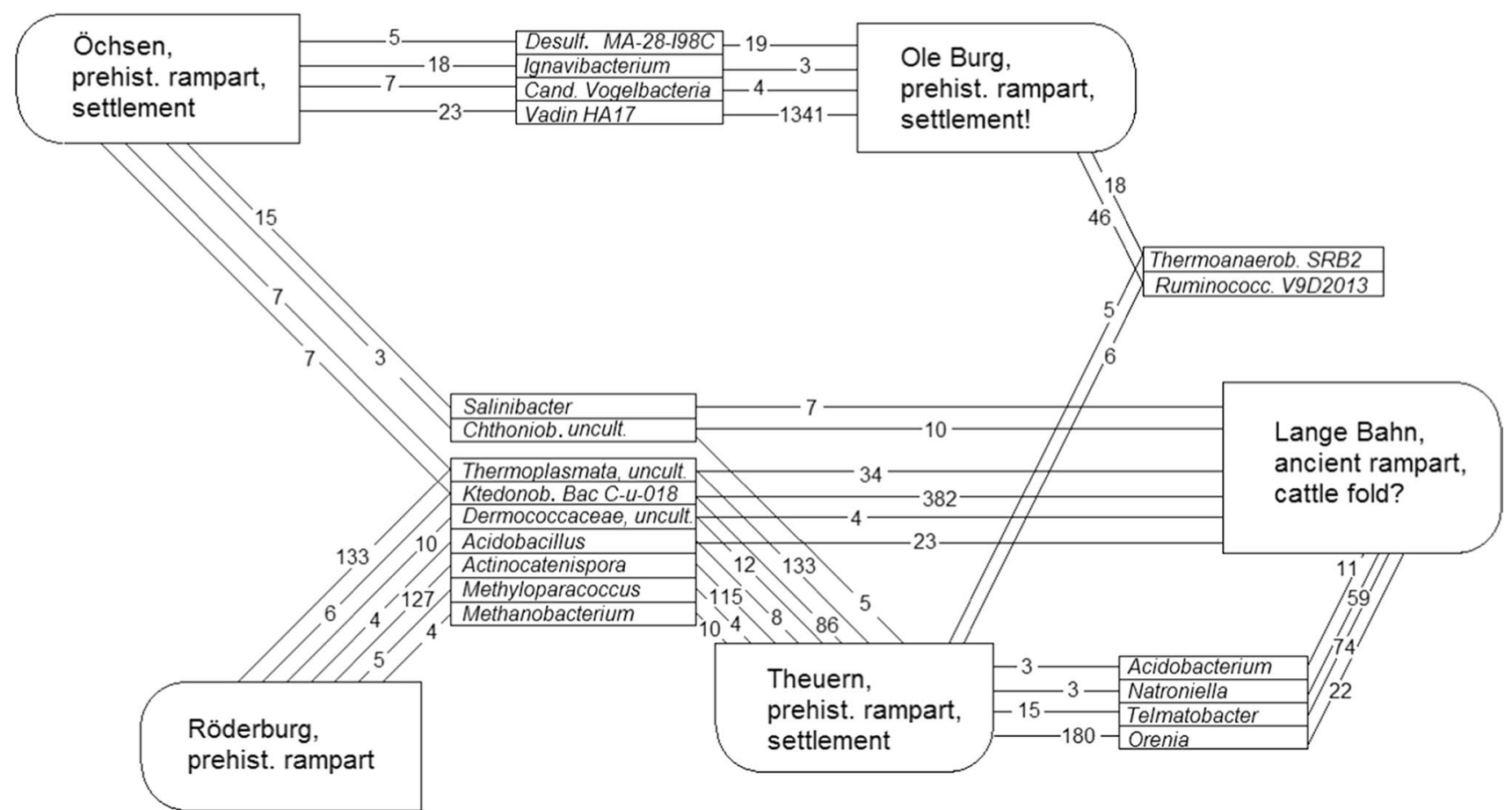

Fig. 7 Relations between samples of selected rampart hills by groups of minority OTUs found in the 16S-RNA profiling (the numbers give the total number of reads of the single OTUs for the related places)

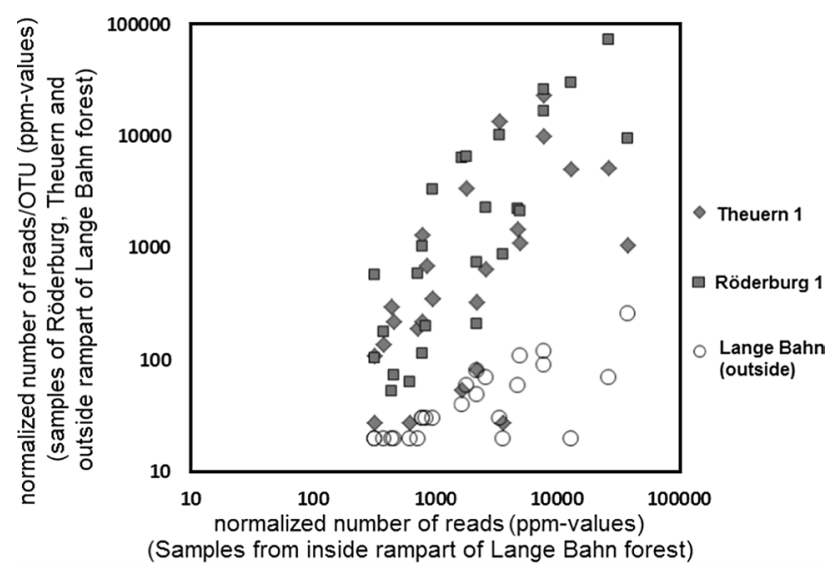

Fig. 8 Normalized numbers of reads (ppm values, 0 set to "20") for samples no. 4c (Röderburg, diamonds) and 9a (Theuern, squares) versus the reads of the inner part of Lange Bahn in comparison with the samples from outside Lange Bahn (open circles), selected OTUs corresponding to Table 7 of the supplementary material

acidophilic bacteria have been found. The observation of these differences could give a hint on the former use of the concerned wall rampart. It is supposed that this kind of ramparts (so-called Vieh-Halde) was mainly constructed for protecting cattle. The above-discussed asymmetries between inside and outside found OTUs would match to this purpose. Interestingly, the concerned area is a forest, recently, and the assumed construction and use of the rampart date back to centuries, at least, probably back to prehistoric times. Concerning the historical land use situation, the found features of minority components in the bacterial communities could be interpreted by a longterm ecological memory of the place. Two samples from the inner part of the ramparts of Theuern and Röderburg show a distribution pattern of the above-mentioned OTUs (Fig. 8) which is similar to the inner part of the Lange Bahn rampart and significantly different from the samples outside of Lange Bahn.

The observed differences in the compositions of soil bacterial communities in the different samples match the observation that archaeological residues can be distinguished by the analysis of the contained bacteria as it was found, e.g. in case of the investigation of Indigenous ochre from different sites of Australia (Lenehan et al. 2017). Besides the expectation to identify the provenance or archaeological samples, it has to be taken in mind that the mineral substrate and the local environment play a crucial role in the presence of many members of a recent bacterial community. Even though chemical conditions of soil mainly influence the composition of soil bacterial communities, sample-specific bacterial components seem to be present over long time in archaeological samples. This corresponds to the presence of DNA of bacterial human pathogens in ancient human remains and fits the finding that microbial communities are 
sample specific and less dependent on geographical origin (Philips et al. 2017).

\section{Comparison of lower abundant OTUs from samples of prehistoric hill settlements with RNA profiling data from the iron-age burial site near Schöps (Thuringia)}

In an earlier study, NGS profiling of 10 soil samples of an iron-age burial field near Schöps (Germany) supplied characteristic features of the minority OTUs from the interior of urns and external reference soil samples (Köhler et al. 2018). In an analogy to these investigations, it is also possible to look for minority components of the soil bacterial communities that are present on the rampart places and the burial field of Schöps. In Fig. 9, such relations between the results from Schöps and some of the investigated rampart hills are shown. Besides groups of minority OTUs which are present on one rampart, mainly, other groups exist which have been found on two of these places. Thus, one group of OTUs (Pseudoclavibacter, Tepidimicrobium, Renibacterium, Rhodobacteraceae, Rubellimicrobium) connects Schöps with Hasenburg and Monraburg samples (both limestone substrate), another group (Gordonia, Agreia, Yonghparkia) with Hasenburg and Steinsburg (basalt substrate).
A significant set of minority OTUs relates the soil bacterial community of Schöps samples with the samples of sandy/quartzite substrate of the rampart of Theuern (Caldibacillus, Caproiciproducens, Methanosarcina, Ureibacillus and Solobacterium), a second set (Desulfurispora, Desulfitibacter, Azospirales, uncult. and Methylophilaceae MM2) to the samples of Ole Burg (limestone), a third (Balneo, uncult., Muribaculaceae, LD1-PA32) to Steinsburg and a forth (Paenibacillaceae, Kurthia, Methanomassiliicoccales, Pigmentiphaga and Cryobacterium) to Hasenburg. In these relations, anaerobic and methanogenic soil bacteria form an important part, too. The strong influence of the local environment on the composition of bacterial communities in the single samples corresponds to investigations on microbial communities inside and on the surface of ancient limestones of Maya buildings (McNamara et al. 2005) which showed significant differences in the epilithic and endolithic bacterial communities with high importance for the conservation of the archaeological residuals. Whereas the above-mentioned organisms reflect the general relations of the samples from Schöps, it is possible to analyse the specific OTUs from the internal material from the urns, too. In another earlier study of ours, significant differences between four of the samples from the urns and the reference material were detected (Köhler et al. 2018). The comparison of these data with the $16 S$ rRNA profiles from the ramparts

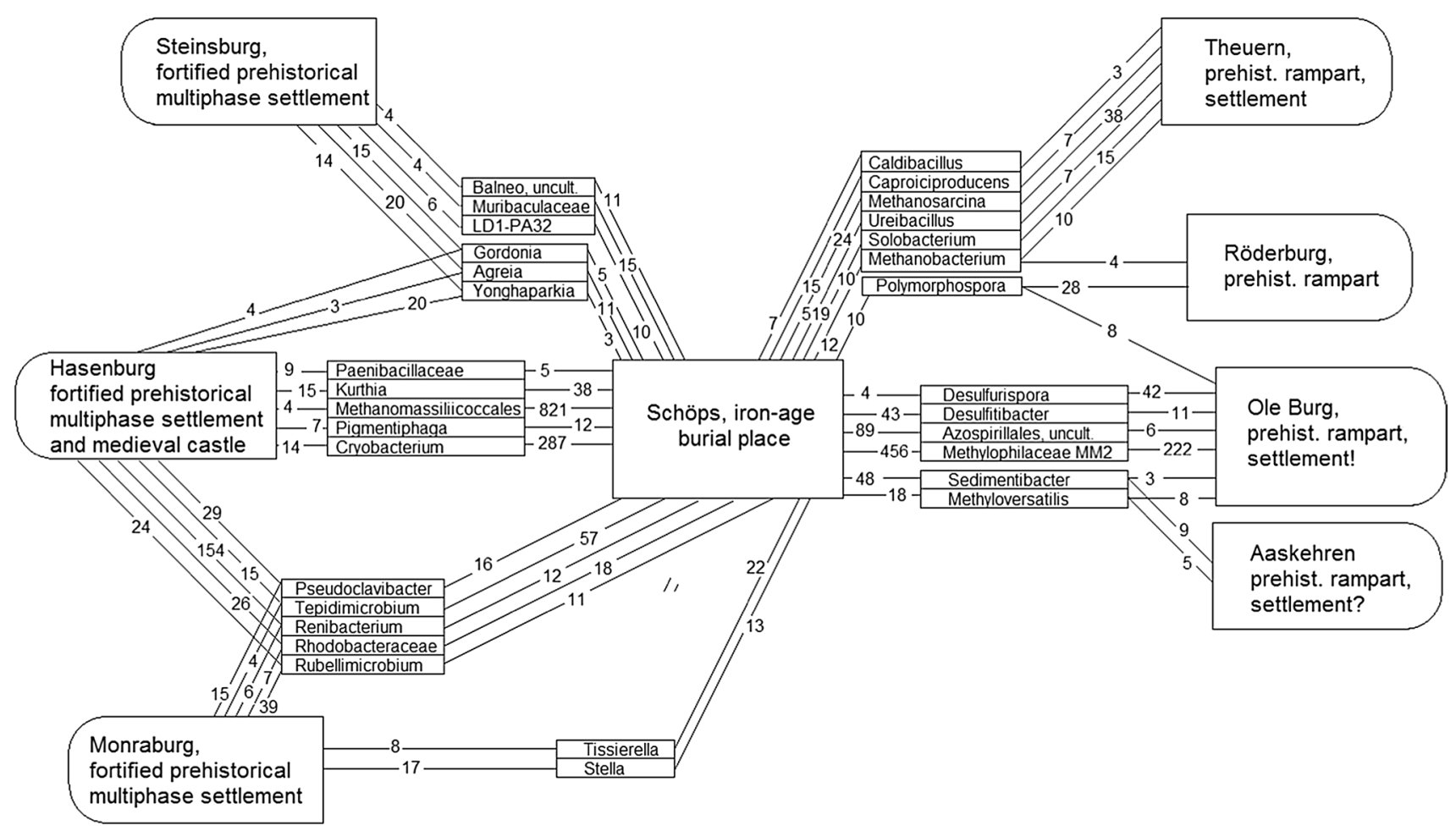

Fig. 9 Relations of samples of selected rampart hills to soil samples of the iron-age burial field of Schöps by groups of minority OTUs found in the 16S-RNA profiling (the numbers give the total number of reads of the single OTUs for the related places) 
speaks of the existence of certain signature-like patterns. Thus, four OTUs (Fodinicola, Sphingobacterales NS11-12 marine group, Sphingobacterales S15-21 group and Adhaeribacter), which had been found in several urns, but not in the reference samples from Schöps, are present significantly at three of the basalt hill ramparts and all limestone hills, but are only partially present in the samples of Röderburg, Theuern and Lange Bahn (data in Table 9 of supplementary material 1).

It is obvious that the observed pattern cannot be explained by the character of soil substrate, exclusively, but might have to do with the historical or even the prehistorical use of the places. Some of the OTUs found in one urn exclusively and seem also to be related to patterns of the rampart communities (data in Table 10 of supplementary material 1). The above-mentioned distribution pattern (significant presence on places number 1 (Steinsburg), 2 (Diesburg), 3 (Öchsen), 5 (Hasenburg), 6 (Monraburg), 7 (Ole Burg) and 8 (Aaskehren) and the absence or low presence on the three other places no. 4, 9 and 10) was also observed for two OTUs (Aquaspirillum arcticum group, Segetibacter) found only in urn sample HB11 and for four OTUs (Polyangiaceae strain, Sulfuriferula, Rhodobacter, Solibacteraceae Elev16S-1166) found only in the urn sample HB13. A certain pattern (Salinimicrobium, Marisediminicola, Alkanindiges) could also be recognized in the samples of places number 2, 5 and 6) for three OTUs of urn sample HB17. In contrast, no hints of signature-like structures could be found for the exclusive OTUs of urn samples HB15 and HB19. Despite the possibility that a part of the observed "signature-like" relations between soil from urns and the investigated samples from hills might be caused accidentally, another part could hint to connections based on a former exchange of plants, animals or organic material. In the recent state of investigations, it is difficult to decide whether these patterns indicate, indeed, a relation between late pre-Roman iron-age soil samples from Schöps and the late Latène period settlements on hills as Steinsburg, Diesburg, Öchsen, Röderburg and Herrenberg near Theuern. In the future, more detailed soil genomic studies including larger metagenomic data sets and whole genome sequencings could allow for identifying such prehistorical connections.

\section{Conclusions}

The 16S rRNA profiling of soil samples from 10 prehistoric ramparts of different regions of Thuringia shows that the bacterial communities of the places can clearly be distinguished by the geological substrate. On the one hand, soil bacteria that are represented in all samples by many reads (majority components) have been found. On the other hand, significant differences for other OTUs, which are highly present in some samples, but low presence or absent in others have been observed. In their presence, the sample origin is important and reflects differences in the composition of soil bacterial communities from a limestone, basalt or sand stone substrate. It was found that these community groups can also be distinguished by majority components from the bacterial communities identified in soil samples from an archaeologically investigated iron-age burial field in the Saale valley near Schöps.

The single samples show partially large differences in less abundant bacterial types (OTUs). These minority components of local soil bacterial communities form in some cases certain patterns, which could be regarded as "signature-like" features of a special soil. Such patterns are not limited to samples of the same soil type, but can also be found between samples of different places and between single samples of the studied ramparts and the interior material of iron-age urns from Schöps. The dominance and the presence or absence of certain OTUs are mainly connected with the acidity of soils. Despite the age of about two thousand years of the urns and continuous leaching by soil water, the cremated remains inside of urns might have contributed to similarities with the communities of limestone places. Other similarities should be regarded as a $\mathrm{pH}$-independent ecological memory of soil. A pH-independent effect of usage past of a place seems to be also responsible for significant differences in the composition of soil communities inside and outside the rampart of Lange Bahn near Suhl. These soil samples are related to the same mineral substrate and are marked by the same $\mathrm{pH}$. They could confirm the assumption of a former concentration of cattle inside the rampart.

The investigations have shown that $16 \mathrm{~S}$ rRNA profiling of soil microbial communities is a valuable tool for the characterization of soils from prehistorically used areas. The results suggest a long-time ecological memory of soils that might be able to reflect earlier land use. It is to expected that more detailed metagenomics studies, the identification of special strains and metabolic potential of local soil microbial communities can supply a lot of information not only on the recent ecological situation but also on the ecological past of a place. Genetic profiling could help in the interpretation of archaeological findings of prehistoric constructions and their original use. Also, they can contribute to understanding the value of long-term anthropogenic effects on the diversity of local microbial communities.

Acknowledgements Open Access funding provided by Projekt DEAL. The support of Steffen Schneider for data processing and of Franziska Kalensee for DNA isolation of a part of the samples is gratefully acknowledged. We thank the BMBF (project BactoCat, Kz. 031A161A) for the financial support of the initial parts of the work.

Open Access This article is licensed under a Creative Commons Attribution 4.0 International License, which permits use, sharing, 
adaptation, distribution and reproduction in any medium or format, as long as you give appropriate credit to the original author(s) and the source, provide a link to the Creative Commons licence, and indicate if changes were made. The images or other third party material in this article are included in the article's Creative Commons licence, unless indicated otherwise in a credit line to the material. If material is not included in the article's Creative Commons licence and your intended use is not permitted by statutory regulation or exceeds the permitted use, you will need to obtain permission directly from the copyright holder. To view a copy of this licence, visit http://creativecommons .org/licenses/by/4.0/.

\section{References}

Aanderud, Z. T., Jones, S. E., Fierer, N., \& Lennon, J. T. (2015). Resuscitation of rare biosphere contributes to pulses of ecosystem activity. Frontiers in Microbiology, 6, 24.

Chernysheva, E., Korobov, D., \& Borisov, A. (2017). Thermophilic microorganisms in arable land around medieval archaeological sites in Northern Caucasus, Russia: Novel evidence of past manuring practices. Geoarchaeology an International Journal, 32, 494-501.

Choi, J. K., Shan, M., \& Yee, N. (2016). Anaerosporomusa subterranean gen nov., sp. nov., a spore-forming anaerobe belonging to the class Negativicutes isolated from saprolite. International Journal of Systematic and Evolutionary Microbiology, 66, 3848-3854.

Donat, P. (1966). Probegrabungen auf dem Oechsen bei Vacha. Kreis Bad Salzungen. Ausgrabungen und Funde, 11, 251.

Douterelo, I., Goulder, R., \& Lillie, M. (2010). Soil microbial community response to land-management and depth, related to the degradation of organic matter in English wetlands: Implications for in situ preservation of archaeological remains. Applied Soil Ecology, 44, 219-227.

Fierer, N., \& Jackson, R. B. (2006). The diversity and biogeography of soil bacterial communities. PNAS, 103, 626-631.

Fierer, N., \& Lennon, J. T. (2011). The generation and maintenance of diversity in microbial communities. American Journal of Botany, 98, 439-448.

Gall, W. (1994). Die Wallanlage auf dem Herrenberg bei Siegmundsburg. Landkreis Neuhaus a. Rwg. Führer zu archäologischen Denkmälern in Deutschland, 28, 160.

Gordon, A. (2010). FASTQ/A short-reads pre-processing tools. http:// hannonlab.cshl.edu/fastx_toolkit/. Accessed 6 Aug 2019.

Haferburg, G., \& Kothe, E. (2010). Metallomics: lessons for metalliferous soil remediation. Applied Microbiology and Biotechnology, 87, 1271-1280.

Hoefman, S., VanderHa, D., Iguchi, H., et al. (2014). Methyloparacoccus murrellii gen. Nov., sp. Nov., a methanotroph isolated from pond water. International Journal of Environmental Research, 64, 2100-2107.

Kazarina, A., Gerhards, G., Peterson-Gordina, E., et al. (2019). Analysis of the bacterial communities in ancient human bones and burial soil samples: Tracing the impact of environmental bacteria. Journal of Archaeological Science, 109, 104989.

Kim, S. B., Lonsdale, J., Seong, C.-H., \& Goodfellow, M. (2003). Streptacidiphilus gen. nov., acidophilic actinomycetes with wall chemotype I and emendation of the family Streptomycetaceae (Waksman and Henrici (1943)AL) emend. Rainey et al. 1997. Antonie van Leeuwenhoek, 83, 107-116.

Kishimoto, N., Kosako, Y., \& Tano, T. (1991). Acidobacterium capsulatum gen. nov., sp. nov.: An acidophilic chemoorganotropic bacterium containing menaquinone from acidic mineral environment. Current Microbiology, 22, 1-7.
Klindworth, A., Pruesse, E., Schwee, T., Peplies, J., Quast, C., Horn, M., et al. (2013). Evaluation of general 16S ribosomal RNA gene PCR primers for classical and next-generation sequencing-based diversity studies. Nucleic Acids Research, 41, e1.

Köhler, J. M., Kalensee, F., Günther, P. M., Schüler, T., \& Cao, J. (2018). The local ecological memory of soil: majority and minority components of bacterial communities in prehistoric urns from Schöps (Germany). International Journal of Environmental Research, 12, 575-684.

Lee, Y. J., Romanek, C. S., Mills, G. L., Davis, R. C., Whitman, W. B., \& Wiegel, J. (2006). Gracilibacter thermotolerans gen. nov., sp. nov., an aerobic, thermotolerant bacterium from a constructed wetland receiving acid sulfate water. International Journal of Systematic and Evolutionary Microbiology, 56, 2089-2093.

Lenehan, C. E., Tobe, S. S., Smith, R. J., \& Popelka-Filcoff, R. S. (2017). Microbial composition analyses by $16 \mathrm{~S}$ rRNA sequencing: A proof of concept approach toprovenance determination of archaeological ochre. PLoS ONE, 12, 0185252. https://doi. org/10.1371/journal.pone.0185252

Lim, J. J., Baek, S. H., \& Lee, S. T. (2009). Ferruginibacter alkalilentus gen. nov., so. nov. And Ferruginibacter Iapsinanis sp. Nov., novel members of the family 'Chitinophagaceae' in the phylum Bacteroidetes, isolated from freshwater sediment. International Journal of Systematic and Evolutionary Microbiology, 59, 2394-2399.

Margesin, R., Siles, J. A., Cajthaml, T., Ohlinger, B., \& Kistler, E. (2017). Microbiology meets archaeology: soil microbial communities reveal different human activities at archaic Monte Iato (sixth century BC). Microbial Ecology, 73, 925-938.

McNamara, Ch J, Perry, Th D, Bearce, K. A., Hernandez-Duque, G., \& Mitchell, R. (2005). Epilithic and endolithic bacterial communities in limestone from a Maya archaeological site. Microbial Ecology, 51, 51-64.

Moodley, Y., Linz, B., Yamaoka, Y., et al. (2009). The people of the pacific from a bacterial perspective. Science, 323, 527-530.

Mouné, S., Eatock, C., \& Matheron, R. (2000). Orenia salinaria sp. nov., a fermentative bacterium isolated from anaerobic sediments of Mediterranean salterns. International Journal of Systematic and Evolutionary Microbiology, 50, 721-729.

Nalin, R., Simonet, P., Vogel, T. M., \& Normand, Ph. (1999). Rhodanobacter lindaniclasticus gen. Nov., sp. Nov., a lindane-degrading bacterium. International Journal of Systematic Bacteriology, 49, $19-23$.

Pankratov, T. A., Kirsanova, L. A., Kaparullina, E. N., Kevbrin, V. V., \& Dedysh, S. N. (2012). Telmatobacter bradus gen. nov., sp. nov., a cellulolytic facultative abaerobe from subdivision 1 of the Acidobacteria, and emended description of Acidobacterium capsulatum Kishimoto et al. 1991. International Journal of Systematic and Evolutionary Microbiology, 62, 430-437.

Peschel, K. (1986). Höhensiedlungen Thüringen im Wandel von der Urnenfelder- zur Hallstattzeit. Veröffentl. Mus. Ur- u. Frühgesch. Potsdam, 20, 29.

Peschel, K. (2004). Die Diesburg bei Meiningen - ein Ort früher Feldforschung in Thüringen. Alt-Thüringen, 37, 5.

Peschel, K. (2005). Die Steinsburg bei Römhild am Rande des nördlichen Mittelgebirgsraumes während der jüngeren vorrömischen Eisenzeit. Alt-Thüringen, 39, 7.

Philips, A., Stolarek, I., Kuczkowska, B., et al. (2017). Comprehensive analysis of microorganisms accompanying human archaeological remains. GigaScience, 6, 1-13.

Quast, C., Pruesse, E., Yilmaz, P., Gerken, J., Schweer, T., Yarza, J. Peplies, et al. (2013). The SILVA ribosomal RNA gene database project: improved data processing and web-based tools. Nucleic Acids Research, 41, D590-D596.

Rickard, et al. (2005). Adhaeribacter aquaticus gen. nov. sp. Nov., a Gram-negative isolate from a potable water biofilm. International 
Journal of Systematic and Evolutionary Microbiology, 55, 821-829.

Rollo, F., \& Marota, I. (1999). How microbial ancient DNA, found in association with human remains, can be interpreted. Philosophical Transactions of the Royal Society of London B, 354, 111-119.

Sekiguchi, Y., Yamada, T., Hanada, S., Ohashi, A., Harada, H., \& Kamagata, Y. (2003). Anaerolinea thermophila gen. nov., sp. nov. And Caldilinea aerophila gen. nov., sp. Nov., novel filamentous thermophiles that represent a previously uncultured lineage of the domain Bacteria at the subphylum level. International Journal of Systematic and Evolutionary Microbiology, 53, 1843-1851.

Simon, K. (1984). Höhensiedlungen der Urnenfelder- und Hallstattzeit in Thüringen. Alt-Thüringen, 20, 23.

Wegner, C. E., \& Liesack, W. (2017). Unexpected dominance of elusive acidobacteria in early industrial soft coal slags. Frontiers Microbiology, 8, 1023.
Wu, X. H., Ge, T. D., Wang, W., et al. (2015). Cropping systems modulate the rate and magnitude of soil microbial autotrophic $\mathrm{CO}_{2}$ fixation in soil. Frontiers Microbiology, 6, 379.

Xu, J., Wei, Y., Jia, H., Xiao, L., \& Gong, D. (2017). A new perspective on studying burial environment before archaeological excavation: analysing bacterial community distribution by high-throughput sequencing. Scientific Reports, 7, 41691.

Yilmaz, P., Parfrey, L. W., Yarza, P., Gerken, J., Pruesse, E., Quast, C., et al. (2014). The SILVA and "All-species Living Tree Project (LTP)" taxonomic frameworks. Nucleic Acid Research, 42, D643-D648.

Zhilina, T. N., Zavarzin, G. A., Detkova, E. N., \& Rainey, F. A. (1996). Natroniella acetigena gen. nov. sp. nov., en extremely haloalkaliphilic, homoacetic bacterium: a new member of haloanaerobiales. International Journal of Systematic and Evolutionary Microbiology, 32, 320-326. 